\title{
Safety and efficacy of ketamine xylazine along with atropine anesthesia in BALB/c mice
}

\author{
Muhammad Ameen Jamal', Arslan Mahmood Ahmed', Muhammad Tahir', Muhammad Ashraf', \\ Abdul Sattar ${ }^{1}$, Aamir Ghafoor ${ }^{2}$, Shahzad Munir ${ }^{3}$, Irfan Ahmed ${ }^{\oplus 4}$, Mubashir Hussain ${ }^{5}$, Amjad Riaz $^{*}$ \\ ${ }^{1}$ Department of Theriogenology, University of Veterinary and Animal Sciences, Lahore, Pakistan, ${ }^{2}$ Department of \\ Microbiology, University Diagnostic Laboratory, Faculty of Veterinary Science, University of Veterinary and Animal Sciences, \\ Lahore, Pakistan, ${ }^{3}$ Faculty of Plant Protection, Yunnan Agricultural University, Kunming, Yunnan, China, ${ }^{4}$ Yunnan Provincial \\ Key Laboratory of Animal Nutrition and Feed, Yunnan Agricultural University, Kunming, Yunnan, PR China, ${ }^{5}$ Vector Borne \\ Diseases Management Center, Department of Microbiology, Kohat University of Science and Technology Kohat, KP, Pakistan
}

\begin{abstract}
Anesthetics are an indispensable prerequisite for surgical intervention and pharmacological animal studies. The objective of present study was to optimize the dose of ketamine (K) and xylazine (X) along with atropine sulfate $(A)$ in order to achieve surgical tolerance in BALB/c mice. Several doses of ketamine $(100,150,200 \mathrm{mg} / \mathrm{kg})$ and xylazine $(10,15,20 \mathrm{mg} / \mathrm{kg})$ were mixed and combination of nine doses $(\mathrm{K} / \mathrm{X}: 100 / 10,100 / 15,100 / 20,150 / 10,150 / 15,150 / 20,200 / 10,200 / 15,200 / 20)$ were evaluated $(\mathrm{n}=9$ per combination). A constant dose of atropine $(0.05 \mathrm{mg} / \mathrm{kg})$ was also used to counter side effect. Timerelated parameters were evaluated on the basis of reflexes. KX at dose $200 / 20 \mathrm{mg} / \mathrm{kg}$ produced surgical tolerance in all nine mice with duration $55.00 \pm 6.87$ minutes. The induction time $0.97 \pm 0.09$ minutes, sleeping time $90.67 \pm 5.81$ minutes and immobilization time (102.23 \pm 6.83 minutes) were significantly higher than all combination. However, this combination was considered unsafe due to $11 \%$ mortality. While, $\mathrm{KX}$ at dose $200 / 15 \mathrm{mg} / \mathrm{kg}$ results in none of the mortality, so was considered as safe. Moreover, this combination produces surgical tolerance in $89 \%$ mice with duration (30.00 7.45 minutes). It was concluded that KX at dose $200 / 15 \mathrm{mg} / \mathrm{kg}$ along with atropine $0.05 \mathrm{mg} / \mathrm{kg}$ is safe for performing surgical interventions in $\mathrm{BALB} / \mathrm{c}$ mice.
\end{abstract}

Keywords: Ketamine hydrochloride. Xylazine hydrochloride. Atropine sulfate. Surgical tolerance. $\mathrm{BALB} / \mathrm{c}$ mice.

\section{INTRODUCTION}

The mouse is regarded as a model animal for biomedical research (Popova et al., 2002). Anesthesia in the mouse is an indispensable prerequisite for surgical interventions as well as pharmacological animal studies (Chong et al., 2016). Moreover, an increasing number of transgenic mouse models are being explored by the scientific community, to evaluate the functional and patho-physiological consequences of gene manipulation (Zuurbier et al., 2014). Anesthesia usually comprises of two or more drugs, because no single drug is consider as an ideal for providing anesthesia (Alves et al., 2009; Arras et al., 2001). Methods of induction and maintenance

\footnotetext{
*Correspondence: Amjad Riaz. Department of Theriogenology, University of Veterinary and Animal Sciences, Lahore, Pakistan. E-mail: riaz_amjad@yahoo.com
}

of anesthesia include gaseous and injectable anesthetics. Although gaseous anesthetics provide good control over anesthesia depth but equipment cost and lack of skilled manpower limit their use (Buitrago et al., 2008).

The selection of anesthetic depends upon drug availability, safety, and attainment of surgical tolerance (Arras et al., 2001). Surgical tolerance is the stage of anesthesia during which animal is completely unconscious from surrounding and has no pain perception (Arras et al., 2001; Buitrago et al., 2008). This is the most significant parameter in the selection of an anesthetic during this stage, and surgical interventions are performed and duration of surgical interventions also depends upon the duration. Mostly dissociative drugs (ketamine, K) with $\alpha_{2}$-agonists (xylazine, $\mathrm{X}$ ) are commonly used for mice (Arras et al., 2001; Chaves, Weinstein, Bauer, 2001; Buitrago et al., 2008; Alves et al., 
2009). But it is documented that, $\mathrm{KX}$ at recommended doses do not produce surgical tolerance in all animals (Arras et al., 2001; Chaves, Weinstein, Bauer, 2001; Dittmar et al., 2004; Kawahara et al., 2005; Chu et al., 2006), therefore, some other drugs are added to produce surgical tolerance. In this regard, acepromazine with $\mathrm{KX}$ is considered as best combination due to its safety and surgical tolerance (Arras et al., 2001; Buitrago et al., 2008). Since acepromazine is not available in the local market, an alternate need to be search and various doses of $\mathrm{KX}$ in conjunction with the new drug need to be readjust.

Anticholinergic drugs such as atropine sulfate (A) are commonly used as pre-anesthetic and reduce hypersalivation and bradycardia induced by ketamine (Wellington, Mikaelian, Singer, 2013). Moreover, atropine along with $\mathrm{KX}$ is frequently used in veterinary practices (Cruz et al., 2000). Therefore, the objective of the present study was to select the best dose of $\mathrm{KX}$ along with atropine that should be safe and produce surgical tolerance for performing surgical interventions in BALB/c mouse.

\section{MATERIAL AND METHODS}

Male BALB/c mice at the age of 9-10 weeks, maintained at mice housing facility, Department of Theriogenology, University of Veterinary and Animal Sciences, Lahore, Pakistan were selected. Mice were housed in 12 hours dark-light cycles and were cared for according to animal protocols approved by the ethical committee. All chemicals were of high grade and purchased from Sigma-Aldrich.

\section{Experimental design}

Three doses $(100,150,200 \mathrm{mg} / \mathrm{kg})$ of ketamine and three doses $(10,15,20 \mathrm{mg} / \mathrm{kg})$ of xylazine along with constant dose $(0.05 \mathrm{mg} / \mathrm{kg})$ of atropine sulfate were mixed. Total nine combinations (KX: 100/10, 100/15, 100/20, $150 / 10,150 / 15,150 / 20,200 / 10,200 / 15,200 / 20)$ with constant dose of atropine $(0.05 \mathrm{mg} / \mathrm{kg})$ were prepared. All combinations were diluted in sterile saline and 0.1 $\mathrm{mL}$ per $10 \mathrm{~g}$ of body weight was injected intraperitoneally (Timeline 1). Once the righting reflex was lost, mice were placed on a heated platform and their eyes were lubricated with normal saline.

The reflexes monitored were cutaneous reflex (CR), tail pinch reflex (TPR), pedal withdrawal reflex (PWR), corneal reflex (Cr.R) and righting reflex (RR). All reflexes were assessed as described previously (Foote, Livingston, 1978; Arras et al., 2001; Buitrago et al., 2008; Stoicea et al., 2016). Briefly, the CR was assessed by pinching needle at the abdomen. The TPR was monitored by pinching at the tip of the tail. For assessing PWR, the hind limb was slightly extended and the interdigital webbing of the foot firmly was pinched between thumb and index finger and this reflex was monitored alternatively between the left and right hind limbs. Movement from

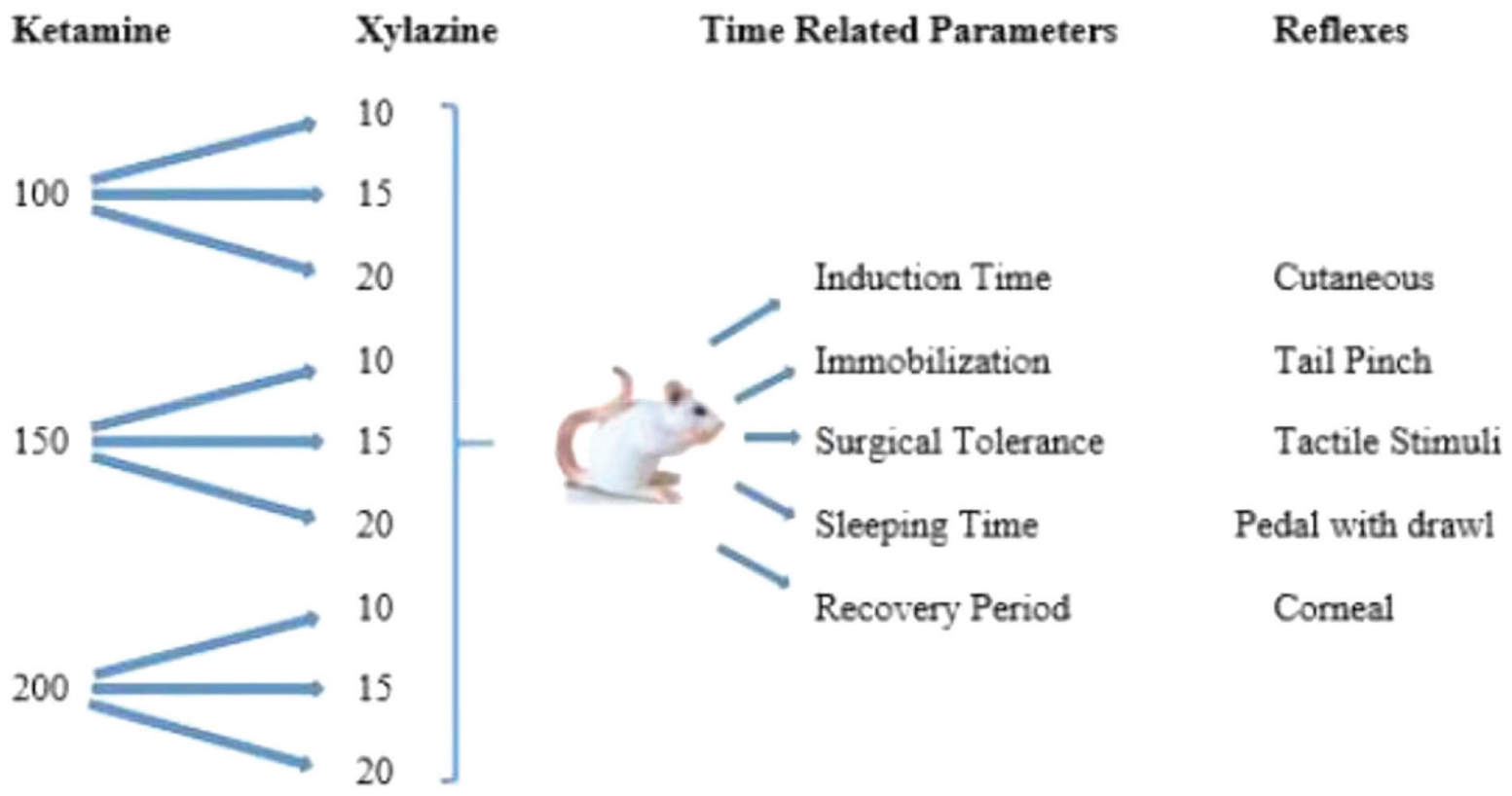

TIME LINE 1 - Experimental Design. A constant dose of atropine $(0.05 \mathrm{mg} / \mathrm{kg})$ was added in each combination and $\mathrm{n}=9$ mice per each combination were used. 
dorsal to sternal recumbency was considered RR. All these reflexes were monitored from loss of RR to spontaneous movement at the interval of five minutes. Reflexes were monitored by scoring system: 0 (no response), 1 (weak response), 2 (moderate response) and 3 (strong response). Time-related parameters are demonstrated in timeline 2. All parameters were assessed by the same operator to reduce variability in the experiment.

\begin{tabular}{lll}
\hline Time & Definition & Intervals \\
\hline T0 & Time of injection & T0-T1-Induction Time \\
T1 & Loss of righting reflex & T1-T3-Immobilization \\
T2 & Loss of motion & T1-T4-Sleeping Time \\
T3 & Spontaneous Movement & T3-T4-Recovery Period \\
T4 & Regain of righting reflex & \\
\hline
\end{tabular}

TIME LINE 2 - Time related parameters

\section{Data analysis}

The statistical analyses were performed using statistical software SAS Enterprise Guide (version 4.2; SAS Inst. Inc., Cary NC, USA) and statistical significance was set at $p<0.05$. Data for all parameters were presented as mean \pm S.E.M. The means were separated using Tukey's test. Data for three doses of two anesthetic groups were analyzed as 3 x 3 factorial model using Proc Mixed procedure of SAS. The groups were separated using pdmix 800 utility. Chi-square test was used for analyses of the number of mice attaining surgical tolerance.

\section{RESULTS AND DISCUSSION}

All doses of ketamine and xylazine along with atropine were evaluated for their safety on the basis of mice attaining surgical tolerance and death rate. The surgical tolerance (Table I) showed that highest dose of KX $(200 / 20 \mathrm{mg} / \mathrm{kg})$ produced surgical tolerance in all nine mice with maximum duration $55.00 \pm 6.87$ minutes and $11 \%$ death rate (1/9). While 200/15 mg/kg KX produced surgical tolerance in eight mice without any death. Hence $200 / 15 \mathrm{mg} / \mathrm{kg} \mathrm{KX}$ was consider as a safe. Furthermore, induction time at $200 / 15 \mathrm{mg} / \mathrm{kg} \mathrm{KX}$ was comparable with all combinations except $100 / 10,100 / 20 \mathrm{mg} / \mathrm{kg} \mathrm{KX}$. However, the duration of immobilization (102.23 \pm 6.83 minutes) and surgical tolerance (55.00 \pm 6.87 minutes) at $200 / 20 \mathrm{mg} / \mathrm{kg} \mathrm{KX}$ was significantly higher from other combinations. Similarly, the sleeping time at KX $(200 / 20 \mathrm{mg} / \mathrm{kg})$ was significantly higher than other combinations except KX $(200 / 10 \mathrm{mg} / \mathrm{kg})$. While the recovery period at $\mathrm{KX}(200 / 15 \mathrm{mg} / \mathrm{kg})$ was comparable with all combination. When the duration of different reflexes was analyzed, the duration of PWR, CR, TPR, Cr.R, and TS at KX (200/20 mg/kg) was significantly higher (Table II) than other combinations. Duration for the onset of different reflexes (Table III) represented that onset of CR, Cr.R, and TS was quick in KX $(200 / 20 \mathrm{mg} / \mathrm{kg})$ as compared to other combination suggesting that the onset of these reflexes result after injecting anesthesia. However, the onset of PWR and TPR in KX $(200 / 20 \mathrm{mg} / \mathrm{kg})$ were comparable with others.

TABLE I - Comparison of safety, efficacy and time related parameters using different doses of ketamine/xylazine in BALB/c mouse

\begin{tabular}{|c|c|c|c|c|c|c|c|c|c|}
\hline Anesthetic* & Ketamine 100 & Ketamine 100 & Ketamine 100 & Ketamine 150 & Ketamine 150 & Ketamine 150 & Ketamine 200 & Ketamine 200 & Ketamine 200 \\
\hline$(\mathrm{mg} / \mathrm{kg})$ & Xylazine 10 & Xylazine 15 & Xylazine 20 & Xylazine 10 & Xylazine 15 & Xylazine 20 & Xylazine 10 & Xylazine 15 & Xylazine 20 \\
\hline \multicolumn{10}{|l|}{ Safety margin } \\
\hline Death rate & $0 / 9$ & $0 / 9$ & $0 / 9$ & $0 / 9$ & $0 / 9$ & $0 / 9$ & $0 / 9$ & $0 / 9$ & $1 * * / 9$ \\
\hline \multicolumn{10}{|c|}{ Time related parameters (minutes) } \\
\hline Immobilization & $49.68 \pm 6.46^{\mathrm{a}}$ & $55.00 \pm 5.33^{\mathrm{ab}}$ & $49.40 \pm 4.94^{\mathrm{b}}$ & $67.83 \pm 6.24^{\mathrm{ab}}$ & $54.31 \pm 5.07^{\mathrm{ab}}$ & $77.27 \pm 14.10^{\mathrm{b}}$ & $83.25 \pm 6.48^{b}$ & $66.87 \pm 12.47^{\mathrm{ab}}$ & $102.23 \pm 6.83^{\mathrm{c}}$ \\
\hline $\begin{array}{l}\text { Duration } \\
\text { of Surgical } \\
\text { Tolerance }\end{array}$ & $15.00 \pm 5.8^{\mathrm{ab}}$ & $11.66 \pm 4.78^{\mathrm{b}}$ & $6.66 \pm 4.16^{\mathrm{b}}$ & $18.33 \pm 7.12^{\mathrm{ab}}$ & $18.33 \pm 6.87^{\mathrm{ab}}$ & $8.33 \pm 4.48^{\mathrm{b}}$ & $19.44 \pm 6.37^{\mathrm{ab}}$ & $30.00 \pm 7.45^{\mathrm{a}}$ & $55.00 \pm 6.87^{\mathrm{c}}$ \\
\hline Sleeping Time & $41.69 \pm 5.79^{\mathrm{a}}$ & $49.20 \pm 4.01^{\mathrm{ab}}$ & $41.77 \pm 4.46^{\mathrm{a}}$ & $56.69 \pm 4.96^{\mathrm{abc}}$ & $48.88 \pm 4.25^{\mathrm{ab}}$ & $64.10 \pm 12.27^{\mathrm{ab}}$ & $65.35 \pm 5.86^{\mathrm{cd}}$ & $55.05 \pm 10.96^{\mathrm{abc}}$ & $90.67 \pm 5.81^{\mathrm{d}}$ \\
\hline
\end{tabular}

Data are presented as mean $\pm \mathrm{SD}, *$ Dose of atropine sulfate in all combination was constant $(0.05 \mathrm{mg} / \mathrm{kg})$, Number ofmice in each group were constant ( $\mathrm{n}=9)$, Depth and quality of anesthesia was characterized by use of reflex test and response to different stimuli, **one mouse died during anesthesia, a-d denote significant difference $(\mathrm{p}<0.05)$ within row. Values with same letters denote non-significant difference $(\mathrm{p}>0.05)$. 
TABLE II - Comparison of duration of various reflexes using different doses of ketamine/xylazine in BALB/c mouse

\begin{tabular}{|c|c|c|c|c|c|c|c|c|c|}
\hline Anesthetic* & Ketamine 100 & Ketamine 100 & Ketamine 100 & Ketamine 150 & Ketamine 150 & Ketamine 150 & Ketamine 200 & Ketamine 200 & Ketamine 200 \\
\hline$(\mathrm{mg} / \mathrm{kg})$ & Xylazine 10 & Xylazine 15 & Xylazine 20 & Xylazine 10 & Xylazine 15 & Xylazine 20 & Xylazine 10 & Xylazine 15 & Xylazine 20 \\
\hline \multicolumn{10}{|c|}{ Duration of various reflexes } \\
\hline Cutaneous & $36.11 \pm 5.45^{\mathrm{a}}$ & $46.11 \pm 5.51^{\mathrm{abc}}$ & $39.44 \pm 5.10^{\mathrm{ac}}$ & $59.44 \pm 4.67 \mathrm{~b}$ & $45.56 \pm 4.20^{\mathrm{abc}}$ & $58.33 \pm 10.47^{\mathrm{bc}}$ & $65.00 \pm 7.02^{\mathrm{bd}}$ & $50.00 \pm 9.86^{\mathrm{abc}}$ & $82.78 \pm 7.46^{\mathrm{d}}$ \\
\hline Tail pinch & $27.22 \pm 5.66^{\mathrm{a}}$ & $27.78 \pm 5.53^{\mathrm{a}}$ & $30.56 \pm 5.56^{\mathrm{a}}$ & $49.44 \pm 4.75^{\mathrm{b}}$ & $33.89 \pm 3.98^{\mathrm{ab}}$ & $36.67 \pm 8.98^{\mathrm{ab}}$ & $45.56 \pm 5.49^{\mathrm{ab}}$ & $45.56 \pm 9.73^{\mathrm{ab}}$ & $72.78 \pm 7.51^{\mathrm{c}}$ \\
\hline Tactile stimuli & $37.78 \pm 5.47^{\mathrm{a}}$ & $46.11 \pm 5.51^{\mathrm{ab}}$ & $41.11 \pm 4.98^{\mathrm{ab}}$ & $59.44 \pm 4.67^{\text {bc }}$ & $46.11 \pm 4.39^{\mathrm{ab}}$ & $60.56 \pm 11.07^{\mathrm{bc}}$ & $67.78 \pm 7.17^{\mathrm{cd}}$ & $53.33 \pm 10.77^{\mathrm{abc}}$ & $82.78 \pm 7.46^{\mathrm{d}}$ \\
\hline
\end{tabular}

Data are shown as mean $\pm \mathrm{SD}$, All reflexes were monitored after loss of righting reflex till spontaneous movement at 5 minute interval, $*$ Dose of atropine sulfate in all combination was constant $(0.05 \mathrm{mg} / \mathrm{kg})$ Number of mice in each group were constant $(\mathrm{n}=9)$, Depth and quality of anesthesia was characterized by use of reflex test and response to different stimuli, ${ }^{\text {a-d }}$ denote significant difference $(\mathrm{p}<0.05)$ within row. Values with same letters denote non-significant difference $(\mathrm{p}>0.05)$.

TABLE III - Comparison of onset of various reflexes of anesthesia using different doses of ketamine/xylazine in mouse

\begin{tabular}{|c|c|c|c|c|c|c|c|c|c|}
\hline $\begin{array}{l}\text { Anesthetic* } \\
(\mathrm{mg} / \mathrm{kg})\end{array}$ & $\begin{array}{c}\text { Ketamine } 100 \\
\text { Xylazine } 10\end{array}$ & $\begin{array}{cc}\text { Ketamine } & 100 \\
\text { Xylazine } & 15\end{array}$ & $\begin{array}{c}\text { Ketamine } 100 \\
\text { Xylazine } 20\end{array}$ & $\begin{array}{c}\text { Ketamine } 150 \\
\text { Xylazine } 10\end{array}$ & $\begin{array}{c}\text { Ketamine } 150 \\
\text { Xylazine } 15\end{array}$ & $\begin{array}{c}\text { Ketamine } 150 \\
\text { Xylazine } 20\end{array}$ & $\begin{array}{c}\text { Ketamine } 200 \\
\text { Xylazine } 10\end{array}$ & $\begin{array}{c}\text { Ketamine } 200 \\
\text { Xylazine } 15\end{array}$ & $\begin{array}{cc}\text { Ketamine } & 200 \\
\text { Xylazine } & 20\end{array}$ \\
\hline \multicolumn{10}{|c|}{ Onset of various reflexes } \\
\hline Cutaneous & $0.50 \pm 0.50^{\mathrm{ab}}$ & $1.00 \pm 0.61^{\mathrm{abc}}$ & $1.67 \pm 0.83^{\mathrm{ac}}$ & $0.50 \pm 0.50^{\mathrm{ab}}$ & $0.83 \pm 0.53^{\mathrm{abc}}$ & $1.67 \pm 0.83^{\mathrm{ac}}$ & $1.88 \pm 0.41^{\mathrm{c}}$ & $0.63 \pm 0.41^{\mathrm{ab}}$ & $0.00 \pm 0.00^{\mathrm{b}}$ \\
\hline Tactile stimuli & $0.00 \pm 0.00$ & $1.00 \pm 0.61^{\mathrm{a}}$ & $0.00 \pm 0.00$ & $0.00 \pm 0.00$ & $0.00 \pm 0.00$ & $0.00 \pm 0.00$ & $0.00 \pm 0.00$ & $0.00 \pm 0.00$ & $0.00 \pm 0.00$ \\
\hline
\end{tabular}

Data are shown as mean $\pm \mathrm{SD}$, All reflexes were monitored after loss of righting reflex till spontaneous movement at 5 minute interval The data demonstrate that onset of pedal withdrawal reflex was late as compared to other reflexes, *Dose of atropine sulfate in all combination was constant $(0.05 \mathrm{mg} / \mathrm{kg})$. Number of mice in each group were constant $(\mathrm{n}=9),{ }^{\mathrm{a}-\mathrm{d}}$ denote significant difference $(p<0.05)$ within row. Values with same letters denote non-significant difference $(p>0.05)$.

The significance of an anesthetic depend on safety and efficacy which is evaluated on the basis of mortality rate and surgical tolerance (Arras et al., 2001). In the present study, the attainment of this stage was observed in dose-dependent manner. Five mice (out of nine) attained at the lowest dose (KX: 100/15 mg/kg) and all mice (9/9) attained at the highest dose (KX: $200 / 20 \mathrm{mg} / \mathrm{kg}$ ). The duration of surgical tolerance was also dose-dependent. The lowest dose of KX $(100 / 10 \mathrm{mg} / \mathrm{kg})$ produce $15.00 \pm 5.8$ minutes while the highest dose $(200 / 20 \mathrm{mg} / \mathrm{kg} \mathrm{KX})$ produce $55.00 \pm 6.87$ minutes. However, some variations were observed at dose 100/20 $\mathrm{KX}$ and $150 / 20 \mathrm{mg} / \mathrm{kg} \mathrm{KX}$ as only three mice (3/9) attained tolerance with low duration (Table I). Similar variations about $\mathrm{KX}$ are already reported (Green et al., 1981). The possible reason for such variability are mouse age, nutrition, and liver metabolism. It is documented that short-term fasting before anesthesia leads to increase drug metabolism resulting in decrease response. Moreover, failure of injection site (injection into muscle or sub cut tissue instead of peritoneum) may be another contributing factor because up to $20 \%$ failure rate had been reported (Struck et al., 2011).

The data for mortality rate revealed that all doses of $\mathrm{KX}$ are safe for mouse except the highest one (KX: 200/20 mg/kg) as one mouse (1/9) was found dead at this dose (Table I). The death may be due to hypotension (Picollo et al., 2012), cardiac arrhythmias and hypersalivation (Green et al., 1981) produced by KX. These findings were not in line with previous studies where it was reported that $\mathrm{KX}$ caused significant mortalities at the recommended dose. The decreased mortality could be due to the addition of the anticholinergic drug, atropine sulfate as it subsides cardiac dysfunctions and hypersalivation. Moreover, atropine produces sedation by crossing blood brain-barrier (Lu et al., 2014) and also increase the sleeping time (Foote, Livingston, 1978). Furthermore, age, sex, genetic and environmental factors as well as inherent 
inter-individual variability might have contributed to anesthetic variability (Struck et al., 2011).

The purpose of anesthesia is analgesia and unconsciousness. Different reflexes such as cutaneous reflex, tail pinch reflex, pedal withdrawal reflex, corneal reflex and tactile stimuli (Green et al., 1981; Arras et al., 2001) were used for pain perception and anesthesia depth. The onset of all reflexes revealed that PWR disappeared later and re-appeared earlier than other reflexes (Table III). Although cutaneous reflex, tail pinch reflex, tactile stimulus were also used for pain perception, their onset was earlier and remained absent while PWR was still present. Hence, PWR is the best indicator of anesthetic depth as it disappears later and reappears earlier than all other reflexes (Arras et al., 2001; Buitrago et al., 2008; Alves et al., 2009; Struck et al., 2011). The duration of loss of PWR was increased with dose and maximum duration (55.00 \pm 6.87 minutes) was observed at the highest dose (KX: 200/20 mg/kg) (Table II). However, the duration was compromised at (KX: 100/20,150/20 mg/kg). This may be due to the decrease in response of mice attaining surgical tolerance (Table I). Moreover, inter-individual variations are also reported at same dose. The duration of PWR revealed that KX: $200 / 20 \mathrm{mg} / \mathrm{kg}$ is the best than all other doses as it produces 55.00 \pm 6.87 minutes anesthesia.

On the basis of attainment of surgical tolerance, and loss of reflexes although KX; 200/20 mg/kg was the best for surgical interventions but one mouse (1/9) was found dead which render this dose unsafe to be used as anesthesia. While KX: 200/15 mg/kg was considered safe as no mouse found dead (Table I). Moreover, this dose produces surgical tolerance of $30.00 \pm 7.45$ minutes. This dose was considered best for surgical intervention.

Best anesthetic is one which has minimum induction, acceptable surgical tolerance and quick recovery with no mortalities. The dose (KX: 200/15 mg/kg) has the similar response like low induction time ( $1.04 \pm 0.17$ minutes) with the surgical tolerance of 30 minutes. Moreover, the recovery period was minimized ( $11.85 \pm 3.3$ minutes $)$ without mortality (Table I). However, some surgeons prefer anesthetic with minimum duration to potentiate their efficiency so they use lower doses of anesthetics. Although minimum duration was achieved at lower doses (KX: $100 / 10 \mathrm{mg} / \mathrm{kg}$ ) but the number of mice attaining surgical tolerance were compromised (5/9). Furthermore, the variability of the individual mouse to same anesthetic dose revealed that there is no standard anesthetic combination as there is no standard mouse (Arras et al., 2001; Zuurbier et al., 2014). So, each laboratory maintain own standard according to experimental design. Hence, KX $(200 / 15 \mathrm{mg} / \mathrm{kg})$ was suggested to be the best dose.
It is acknowledged that $\mathrm{KX}$ with acepromazine is considered suitable for the mouse but in the present study, we reported first time that $\mathrm{KX}$ along with atropine is also suitable combination to produce surgical tolerance without significant mortalities. Present study results were comparable to previous reports as $\mathrm{KX}$ with acepromazine produces surgical tolerance in $85 \%$ mice $(17 / 20)$ (Arras et al., 2001) while KX with atropine result in surgical tolerance in $88 \%$ mice (8/9). Moreover, induction time, immobilization, duration of surgical tolerance and recovery periods were also comparable to KX with acepromazine (Arras et al., 2001; Buitrago et al., 2008).

It is concluded that ketamine: xylazine along with atropine at dose rate $200 / 15 / 0.05 \mathrm{mg} / \mathrm{kg}$ is suitable for surgical interventions in $\mathrm{BALB} / \mathrm{c}$ mouse. However, further studies should be conducted to observe cardiac dynamics and physiological parameters for this combination.

\section{ACKNOWLEDGMENTS}

Authors are thankful to Higher Education Commission (HEC; 20-2242/R\&D/11-2455) Pakistan for providing funds to establish mice colony and embryology laboratory in Department of Theriogenology, University of Veterinary and Animal Sciences, Lahore, Pakistan and to Dr. Mushtaq Ahmed, Lecturer, Department of Theriogenology, for statistical analyses.

\section{REFERENCES}

Alves HC, Valentim AM, Olsson IA, Antunes LM. Intraperitoneal anesthesia with propofol, medetomidine, and fentanyl in mice. Lab Anim. 2009; 43(1):27-33.

Arras M, Autenried P, Rettich A, Spaeni D, Rulicke T. Optimization of intraperitoneal injection anesthesia in mice: Drugs, dosages, adverse effects, and anesthesia depth. Comp Med. 2001; 51(5):443-456.

Buitrago S, Martin TE, Tetens-Woodring J, Belicha-Villanueva A, Wilding GE. Safety and efficacy of various combinations of injectable anesthetics in bulb/c mice. J Am Assoc Lab Anim Sci. 2008; 47(1):11-17.

Chaves AA, Weinstein DM, Bauer JA. Non-invasive echocardiographic studies in mice: Influence of anesthetic regimen. Life Sci. 2001; 69(2):213-222. 
Chong H, Ogata Y, Niwa H, Kushikata T, Watanabe H, Imaizumi T, Hirota K, Ono K, Ohba T, Murakami M. The cardiorespiratory responses to inhalation and pentobarbital anesthesia in the mouse. Hirosaki Med J. 2016; 67:77-85.

Chu DK, Jordan MC, Kim JK, Couto MA, Roos KP. Comparing isoflurane with tribromoethanol anesthesia for echocardiographic phenotyping of transgenic mice. J Am Assoc Lab Anim Sci. 2006; 45(4):8-13.

Cruz ML, Luna SP, De Castro GB, Massone F, Rosa AL. A preliminary trial comparison of several anesthetic techniques in cats. Can Vet J. 2000; 41(6):481-485.

Dittmar MS, Fehm NP, Vatankhah B, Horn M. Ketamine/ xylazine anesthesia for radiologic imaging of neurologically impaired rats: Dose-response, respiratory depression, and management of complications. Comp Med. 2004; 54(6):652655.

Foote G, Livingston A. A comparison of the effects of physostigmine and atropine on ketamine, Althesin and Pentobarbitone anesthesia in rats [proceedings]. J Physiol. 1978;284:132P-133P.

Green CJ, Knight J, Precious S, Simpkin S. Ketamine alone and combined with diazepam or xylazine in laboratory animals: A 10-year experience. Lab Anim. 1981; 15(2):163-170.

Kawahara Y, Tanonaka K, Daicho T, Nawa M, Oikawa R, Nasa Y, Takeo S. Preferable anesthetic conditions for echocardiographic determination of murine cardiac function. $\mathrm{J}$ Pharmacol Sci. 2005; 99(1):95-104.

Lu D-Z, Jiang S, Yu S-M, Fan H-G. A comparison of anesthetic and cardiorespiratory effects of tiletamine-zolazepam/xylazine and tiletamine-zolazepam/xylazine/tramadol in dogs. Pak Vet J. 2014; 34(1):63-7.
Picollo C, Serra AJ, Levy RF, Antonio EL, Santos LD, Tucci PJF. Hemodynamic and thermoregulatory effects of xylazineketamine mixture persist even after the anesthetic stage in rats. Arq Bras Med Vet Zoot. 2012; 64(4):860-864.

Popova E, Krivokharchenko A, Ganten D, Bader M. Comparison between PMSG and FSH-induced superovulation for the generation of transgenic rats. Mol Reprod Dev. 2002; 63(2):177182.

Stoicea N, Versteeg G, Florescu D, Joseph N, Fiorda-Diaz J, Navarrete V, Bergese SD. Ketamine-based anesthetic protocols and evoked potential monitoring: A risk/benefit overview. Front Neurosci. 2016;10:37.

Struck MB, Andrutis KA, Ramirez HE, Battles AH. Effect of a short-term fast on ketamine-xylazine anesthesia in rats. J Am Assoc Lab Anim Sci. 2011; 50(3):344-348.

Wellington D, Mikaelian I, Singer L. Comparison of ketaminexylazine and ketamine-dexmedetomidine anesthesia and intraperitoneal tolerance in rats. J Am Assoc Lab Anim Sci. 2013; 52(4):481-487.

Zuurbier CJ, Koeman A, Houten SM, Hollmann MW, Florijn WJ. Optimizing anesthetic regimen for surgery in mice through minimization of hemodynamic, metabolic, and inflammatory perturbations. Exp Biol Med. 2014; 239(6):737-746.

Received for publication on $20^{\text {th }}$ April 2017 Accepted for publication on $23^{\text {rd }}$ September 2018 